\title{
Effect of Feeding Levels and Feeding Frequency on Growth Performance and Feed Utilization of Red Tilapia Fingerlings (Tilapia hornorum X Tilapia mossambicus) .
}

\author{
Gaber Desouky Ibrahim Hassanen ${ }^{1}$.. Ashraf Y. El-Dakar ${ }^{1}$ \\ Ahmed Kamel EL-Hammady ${ }^{2}$.Heba Abass Elssayed Awed ${ }^{1}$ \\ 1. Faculty of Environmental Agricultural Sciences, Suez Canal University, \\ El-Arish, North Sinai, Egypt \\ 2. National Institute of Oceanography and Fisheries, Egypt.
}

\begin{abstract}
The present study was carried out at the Mariculture research center (M.R.C.) of the Suez Canal University, EL-Arish, North Sinai, Egypt. It aims to evaluate the feasibility of Red Tilapia culture in salt water. Effect of feeding levels and feeding regimes on growth performance and feed utilization of Red Tilapia fingerlings. Three feeding levels (2, 3 and 4\% of total fish biomass) and within each feeding level two feeding frequency (4 times/day and 6 times/day). The fish had an average initial weight of $5.50 \mathrm{~g}$ and $32 \%$ crude protein were tested .The results showed that: The fish fed on $4 \%$ feeding levels from total fish biomass and 4 times /day have the heaviest final body weight $(29.68+4.35 \mathrm{~g})$ and have a daily weight gain and specific growth rate of $0.28+0.05$ (g/fish/day) and $1.98+0.16$ (\%/day), respectively.
\end{abstract}

Key words: Red Tilapia, Feeding level, feeding regimes, Growth, Feed effinciency.

\section{Introduction}

In Egypt, where fresh water is not plentiful, the competition between agriculture and fish farming tends to increase the pressure on aquaculture to use more marginal areas and water sources less suitable for agriculture .The shortage in fresh water in many countries and the competition for it in agriculture and other urban activities has increased the pressure to develop aquaculture in brackish water and sea water (El-Sayed,2006).Tilapia are important species, especially for tropical aquaculture and euryhaline fish that can live and thrive in a wide range of salinity from fresh water to full sea water even though some species tolerate a wide range of salinity than others (Philippart and Ruwet,1982; Gunner et al.,2005; Kamal and Mari,2005). A survey of the literature suggests that Oreochromis niloticusis not among the more saline tolerant species. Watanabe $\boldsymbol{e t}$ al. (1985) defined O. niloticus as only a moderately salt - tolerant species and suggested that optimizing transfer time from fresh - to salt - water may help improving its performance in saline waters. Acclimation procedures for euryhaline tilapias intended for saline water culture were reviewed by Perschbacher (1992). He reported that, while $O$. mossambicus can be acclimated in a single - step (intermediate salinity directly to final sea water salinity) and requires only one day at the intermediate salinity for sea water acclimation with no mortality; $O$. aureus requires 4 days and $O$. niloticus needs 8 days. AL-Amoudi (1987) compared the salinity tolerance of several species and hybrids and found $O$. aureus, O. spilurus, $O$. mossambicus to be more saline tolerant than other. Villegas (1990) found that $O$. niloticus was significantly less saline tolerant than $O$. mossambicus and their reciprocal F1 hybrids. Doudet (1992) evaluated several species and hybrid for their suitability to be cultured in the brackish waters of lagoon in the lovry coast, $O$. niloticus not the lagoo species, sarotherodon melanotheron and tilapia guineensis were suitable. O. aureus was found best, followed by the $O$. niloticus, $O$. aureus and $O$. mossambicus, O. niloticus hybrids. Several Red Tilapias, such as the Taiwanese (Cheong et al., 1987) and Florida (e.g.Thouard et al., 1990; Watanabe et al. (1990) red strain, originating by hybridization of either $O$. niloticus or $O$. mossambicus, are also considered as saline tolerant. Pongthana et al.(2010) comparative performance of four red tilapia strains and their crosses in fresh- and saline water environments . They found that the growth performance of red tilapia was significantly lower in saline than in freshwater environments $(P<0.001)$.

Ng et al . (2013) show that the use of alternative lipids in tilapia feeds is becoming increasingly commonplace due to the rising cost of fish oil (FO).The results present by same authers appeared that growth performance and feeding efficiencies were not significantly better $(\mathrm{P}>0.05)$ for tilapia fed the FO based-diet than the alternative oil-based diets while none of the body indices or carcass/fillet yield were impacted by the dietary lipid source. The effects of fish oil-enriched diets on growth, feed conversion and fatty acid content of red hybrid tilapia, Oreochromis sp.examined by

Al-Souti et al. (2012). They reported that Juvenile, red hybrid tilapia were fed diets containing cod liver oil $(0 \%, 4 \%, 8 \%, 12 \%$ of total diet) substituted against corn oil. After 10 weeks, no significant 
differences between treatments were seen in weight gain, specific growth rate, feed conversion ratio, whole body or dorsal muscle (fillet) proximate composition.

Thompson et al. (2000) study the effects of different feeding regimes (frequencies) on growth of juvenile sunshine bass. He found at the conclusion of the feeding trial, percentage weight gain of fish fed twice /day were significantly $(\mathrm{p}<0.05)$ higher (342\%) compared to fish fed all other feeding frequencies.To investigate the effect of meal frequency on the utilization of carbohydrate by tilapia, Oreochromis niloticus X O. aureus, diets containing $44 \%$ of different carbohydrate were fed for 8 weeks either two or six times a day. The results indicated that weight gain was significantly higher $(p<0.05)$ for fish fed six times a day than for those fed two times a day (Tung and Shiau, 1991).A feeding trial was conducted to evaluated the appropriate feeding frequency for cage cultured Red Tilapia (O. mossambicus $\mathrm{X} O$. hornorum) in Thailand (Orachunwong et al., 2001). Fish were stocked in floating cages suspended in earthen BW ponds (15-18ppt) and fed a commercial tilapia feed ( $25 \%$ crude protein) adlibitum 2,3 and 4 times daily. Feeding 3-4 times day has resulted in better growth and FCR .Andrews and Page (1975) showed that in channel catfish fed twice daily grew faster and used food more efficiency than fish fed 4 times a day. Jarboe and Grant (1996) showed that neither feeding time nor feeding frequency significantly influence the growth, survival, and body composition of channel catfish raised in closed recirculating raceway systems. han twice a day Wing-Keong et al.(2000) determined the effects of feeding rate on growth, feed utilization and body composition of the tropical bagrid catfish ( Mystus nemurus). Fish fingerlings with an average weight of $12 \mathrm{~g}$ Where fed a practical diet $(36.2 \%$ protein) at rates of $1,2,2.5,3,3.5,4$ or $5 \%$ of their body weight (BW) per day in two equal meals. Percent weight gain increased almost linearly with increasing feeding rates up to $2.5 \% \mathrm{BW} /$ day beyond which no significant ( $p>0.05)$ improvement in weight gain was observed. Riche et al.(2004)determined effect of feeding frequency on gastric evacuation and the return of appetite in tilapia Oreochromis niloticus (L.).They reported that the rate at which food is consumed and the efficiency with which it is utilized are prime factors in determining growth rate. There is a positive relation between growth and feeding frequency. Additionally, feeding frequency is strongly correlated with gastric evacuation time (GET).

The aim of the present study is to test effect of feeding levels and feeding frequency on growth performance and feed utilization of red tilapia fingerlings (Tilapia hornorum $X \quad$ Tilapia mossambicus) .

\section{Materials and methods}

Trials were carried out at the Mariculture Research Center (M.R.C.) of the Suez Canal University, ELArish, North Sinai, Egypt.

\section{Rearing Techniques}

Experimental feed ingredients were blended and milled in an electric blender. The dry feed mixture was mixed with the mixture oil (fish oil+corn oil) and then with a binder solution (1\% agar) to form a past. Then pelleted diets were produced through a mincer which into $0.5 \mathrm{~mm}$ diameter. This diameter was increased from 0.5 to $1.5 \mathrm{~mm}$ as the fish grew. The pellets were dried by air and stored at $20^{\circ} \mathrm{C}$ until used.

\section{Experimental Fish}

Experimental fish were brought from rearing pond from a stock maintained at M.R.C. Fish had an average initial weight of $5.50 \mathrm{~g}$. Represent three feeding levels (2, 3 and $4 \%$ of total biomass of fish) and within each feeding levels tested two feeding frequency (4 times / day and 6 times / day). Fish were distributed into 12 conical bottom fiber glass tanks (125 L capacity, 30 fish /tank,each treatment assayed by duplicates ). The feeding levels and feeding frequency were tested on Red Tilapia during an experimental period of 12 weeks.

\section{Feeding Procedures:}

Composition of the artificial diet used is presented in table (1). The experimental diet which gave the best results is containing $32 \%$ crude protein (Watanabe et al.1990)and $2722 \mathrm{k}$ cal / kg. Fish in each treatment were fed manually their daily amount of feed four or six times daily, six days per week for 12 week. The amount of feed for each treatment was adjusted every two weeks after weighting the fish.

Table 1. Percentage composition of experimental diets

\begin{tabular}{ll}
\hline \multicolumn{1}{c}{ Protein level } & 32 \\
\hline Component & \\
\hline Fish meal & 19 \\
\hline Soybean meal & 32 \\
\hline Yellow corn & 23 \\
\hline Wheat bran & 18 \\
\hline Fish oil & 2 \\
\hline Corn oil proximate & 4 \\
\hline Vitamin premise* & 1 \\
\hline Mineral premix** & 1 \\
\hline The & \\
analysis of & \\
experimental diets: & \\
Crude protein \% & 32.34 \\
Crude fat \% & 9.92 \\
Ash \% & 9.11 \\
\hline
\end{tabular}


Table 1 Cont.

\begin{tabular}{ll}
\hline $\begin{array}{l}\text { Nitrogen } \\
\text { extract*(NFE) }\end{array}$ & free \\
Fiber \% & 6.70 \\
ME (kcal/ kg ) & 2722 \\
P / E ratio(mg cp / & 118.08 \\
kcal) & \\
\hline Vitamin premixe*: A(15000 / I u), D3(1500 / I u), \\
B6(3 mg), E(2 mg), B2(2.5 mg), K3(2.5 mg), B12(5 \\
mg), Nicotine amide (10 mg), Folic acid (2 mg), \\
Cal. Pantothenate (5.5 mg). \\
Mineral premix**: Fe (359 mg), Ca(200 mg), \\
Mg(55mg), Zn(55mg), Se(0.5mg), \\
Cu(10mg), I (1mg).
\end{tabular}

\section{Flesh Analysis:}

The fish were scaled, headed and cut from the tail. The skin, bones and viscera were removed, hence the edible part was obtained. The edible meat was then passed rapidly through a mincer for several times and mixed thoroughly after each turn, the flesh analysis i.e. dry matter, protein, fat and ash were determined according the methods described by A.O.A.C. (1990).

\section{Feed Analysis:}

Chemical analysis of ingredients and diets were done according to the methods described by A.O.A.C. (1990), for crude protein, crude fat, crude fiber, ash and dry matter.

\section{Terminology:}

\section{Growth Rate:}

The growth rate was calculated as average daily again (ADG) and specific growth rate (SGR) as follow:

A.D.G $=\mathrm{W} 2-\mathrm{W} 1 / \mathrm{T}$

S.G.R. \% / day $=($ Ln W2 - Ln W1 / T $) \times 100$

Where: W1: Initial average body weight (g/fish).

W2: Final average body weight (g/fish).

$\mathrm{T}$ : Experimental period.

Ln: Natural logarithm.

Condition Factor $(\mathbf{k})$ :

The condition factor $(\mathrm{k})$ was estimated by the following form

$\mathrm{K}=100 \mathrm{~W} / \mathrm{L} 3$

Where:

$\mathrm{W}$ : body weight in grams.

$\mathrm{L}$ : body length in $\mathrm{cm}$.

\section{Feed Utilization:}

The index of the degree of feed utilization as related to growth was calculated in two ways:

1. Feed conversion (feed consumed (g)/gain (g))

2. The inverse of conversation factor i.e. (weight gain / weight of feed consumed) 100 termed as feed efficiency.

\section{Protein Utilization}

Dietary protein utilization of experimental diets for growth was evaluated by determining the following parameter.
Protein efficiency ratio $(\mathrm{PER})=$ gain $(\mathrm{g}) /$ protein intake $(\mathrm{g})$.

\section{Metabolizable Energy (ME)}

The ME value of the diets were calculated by the formula of N R C(1993) :

$\mathrm{ME}(\mathrm{k} \mathrm{cal} / 100 \mathrm{~g})=3.9(\mathrm{CP} \%)+8.0(\mathrm{EE} \%)+1.6$ (NFE\%)

Where:

$\mathrm{CP}$ : crude protein

EE: Ether extract

NFE: Nitrogen free extract

\section{Water Quality Analysis:}

Experimental fish were reared in fresh sea water. Salinity, temperature, $\mathrm{pH}$, dissolved oxygen and photo period values were $35 \pm 2 \mathrm{ppt}, 26 \pm 2{ }^{\circ} \mathrm{C}, 7.3 \pm$ $0.4,7 \mathrm{ppm}$

\pm 0.6 and 12 hours, respectively. All parameters were determined according to the APHA (1989).

\section{Statistical Analysis:}

All data were carried out using SAS (SAS, 1993). A general linear model (GLM) was used to identify the factors to be included in the statistical models. The analysis of variance, Duncan test (1955)were carried out according to Steel and Torrie (1980).

\section{Results and discussion}

\section{Growth Performance:}

The effects of feeding levels and feeding frequency on Red Tilapia, growth rate per individual fish and summary of growth parameters after 12 weeks of rearing are presented in tables $(2,3)$ respectively.

The results of this trail, revealed that there were no significant differences in final weight and average gain in weight $(\mathrm{P}<0.05)$ for interaction betwwen feeding levels and feeding frequency effects. Fish group fed $4 \%$ feeding rate from their total fish biomass and 4 times/day feeding frequency, showed the heaviest final body weight $(29.68 \pm 4.35 \mathrm{~g})$ followed by group of fish had $3 \% \mathrm{BW} /$ day and 3 times/day. However, the best average daily gain and specific growth rate were recorded with $4 \% \mathrm{BW} /$ day and 4times/day( Table 2).

Many factors are known to modify feed intake in fish such as water temperature, water quality, fish size, feeding frequency, photoperiod, stocking density, and feed quality (NRC, 1993).

These results are in agreement with Orachunwong et al., 2001. Where they reported that Red Tilapia rearing in floating cages suspended in earthen brackish

water ponds (15-18 ppt) and fed $25 \%$ crude protein, feeding 3-4 times/day has results in better growth than twice a day. Dividing the daily ration of tilapia would probably reduce feed loss compared to once or twice a day. Riche $\boldsymbol{e t}$ al $\mathbf{~ ( 2 0 0 4 ) f e d ~ N i l e ~ t i l a p i a ~}$ Oreochromis niloticus to satiation with a pelleted diet at two different feeding frequencies (three meals 
day $^{-1}$ and five meals day ${ }^{-1}$ ) to evaluate the effects of feeding frequency on gastric evacuation and the return of appetite. They found that gastric evacuation rates (GER) for both treatments were curvilinear and were best described by a surface-area dependent model. The equation describing GER for fish fed three meals day ${ }^{-1}$ was $V_{T}=67.0 \mathrm{e}^{-0.153(x)}$ and for fish fed five meals day ${ }^{-1}$ was $V_{T}=85.0 \mathrm{e}^{-0.149(x)}$. The instantaneous evacuation rates obtained by linearizing the data were not significantly different and suggest gastric evacuation is independent of feeding frequency. Fish fed at 4-5-h intervals consume as much as they have evacuated. Fish receiving meals at $2-3-\mathrm{h}$ intervals exhibit gastric overload. The return

of appetite following a satiation meal is approximately $4 \mathrm{~h}$ in Nile tilapia held at $28^{\circ} \mathrm{C}$.

The results indicated that increasing feeding levels (table 6) improved growth parameters. The present study is in agreement with those reported by Santiago et al. (1987) who found that, the growth of Nile Tilapia ( $O$. niloticus) fry increased with increasing feeding levels. In addition Sirol $\boldsymbol{e t}$ al. (2000) found that, growth rates of Red Tilapia fingerlings were increased with increasing feeding levels from 4 to $6 \%$. In this trial Sumagaysay and Borlongan (1995), reported that milk fish (Chanos chanos) juvenile $(5 \mathrm{~g})$ were stocked at $7000 /$ ha and feed two diets containing $24 \%$ or $31 \%$ dietary protein at 2 or $4 \%$ of body weight. Regardless of protein levels, they found the final weight, weight gain, specific growth rate and production of fish were significantly $(\mathrm{p}<0.05)$ higher when fed at $4 \%$ body weight than at $2 \%$.Also, they suggested that it could be to the higher amount of amino acids available for protein synthesis from through greater amount of feed given at higher rate can be compensated by faster growth and higher production. El-Dakar (1999) reported that rabbit fish (Siganus rivulatus) fingerlings fed on 2, 4, 6 and $8 \%$ of body weight, growth performance of fish was to be directly related to feeding levels. It was increased as feeding levels increase.

In contrast, Andrews and Page (1975) showed that in channel catfish fed twice daily grew faster than fish fed 4 times a day.Though, Wing-Keong $\boldsymbol{e t}$ al. (2000) mentioned that percent weight gain increased almost linearly with increasing feeding rates up to $2.5 \% \mathrm{BW} /$ day beyond which no significant $(\mathrm{p}>0.05)$ improvement in weight gain was observed for the tropical bagrid catfish (Mystus nemurus) fingerlings. For feed utilization, FCR, FER, PER and feeding intake (g/fish) were affected by the feeding levels and feeding regimes during 12 weeks of the experimental period(Table 3). However, within each feeding level, the best results of FCR and PER were obtained at $2 \%$. Regardless the feeding rate, fish fed at 4times/day were best utilization of feed( Table3). These results in agreement with Sirol et al.(2000) who found that Red Tilapia fingerlings, FCR were impaired with increasing feeding levels from 4 to $16 \%$. Meanwhile, feed intake increased with increasing feeding levels. For sunshine bass, Thompson et al., (2000)reprted that the amount of diet consumed by fish fed twice/day was significantly higher (119 g diet/fish) compared to fish fed all other feeding frequencies. Feed conversion ratio (FCR) of fish fed twice/day were significantly higher (1.50) compared to fish fed once/day (1.28) and once every other day (1.15) but not different $(p>0.05)$ from fish fed twice every other day (1.35). In this connection, Bashamohideen and Paravtheeswarao,( 1976) showed that feed consumption, digestion and utilization by these fish will be affected by the changes in water salinity. In support, Watanabe $\boldsymbol{e t}$ al.(1988) found that the daily feed consumption of Florida Red Tilapia fed a $32 \%$ crude protein diet increased with increasing salinity from 0.00 to32 ppt. Clark et al. (1990) found that the maximum growth of these fish obtained at satiation feeding rates, while feed conversion was improved at lower feeding rate. El-Dakar (1999) mentioned that, FCR was improved by decreasing the feeding levels. The best FCR value was obtained at low feeding rate $(2 \%$ of biomass weight),however, PER, PPV\% and ER\% were increased with the increase of feeding level for rabbit fish (Siganus rivulatus) fingerlings.

On the other hand, Wing-Keong et al. (2000) determined feed utilization for the tropical bagrid catfish (Mystus nemurus). He found that feed utilization did not differ significantly $(\mathrm{p}>0.05)$ between fish fed 1.0 to $2.5 \% \mathrm{BW} /$ day but decreased when rations were increased to $3.0 \% \mathrm{BW} /$ day and above. Feed efficiency ratio was 0.79 for fish fed $1.0 \% \mathrm{BW} /$ day compared to a ratio of 0.27 for fish fed at $5 \% \mathrm{BW} /$ day. Catfish fed $1.0 \% \mathrm{BW} /$ day had the lowest condition factor. However, the reduction of feed conversion ratio with increasing feeding levels may be due to the increasing rate of feed passage through the digestive tract and depressed feed digestibility and metabolism, leading to poor feed efficiency, as reported by Macintosh and Silva (1984) and El-Sayed (2002).

Results of this study were shown that the effects of feeding levels and feeding regimes on flesh composition after 12 weeks of Red Tilapia did not significantly $(\mathrm{p}>0.05)$ influenced( Table 3 ). However, the lowest value for fat content was achieved with fish fed $4 \%$ of body weight. The body composition of fish can be affected by several factors, including species, environmental condition, dietary protein level and feeding rate (Ogata and Shearer, 2000). Our results are in agreement with Sayed ( 2005) who reported that at $4 \%$ feeding rate for mono sex Nile tilapia, produced significantly lower protein and lipid contents in fish body. Also,Wing-Keong et al. (2000) for tropical bagrid catfish, fed at $5 \% \mathrm{BW} /$ day had lower proportion of whole body dry matter, lipid and protein. 
Table 2. Growth parameters (Mean \pm SD) at different feeding levels and feeding frequencies

\begin{tabular}{|c|c|c|c|c|c|c|}
\hline Feeding levels \% & & & & & & \\
\hline $\begin{array}{l}\text { Feeding frequencies } \\
\text { Per day }\end{array}$ & 4 & 6 & 4 & 6 & 4 & 6 \\
\hline $\begin{array}{l}\text { Initial body weight } \\
\text { (g / fish ) }\end{array}$ & $\begin{array}{l}5.80 \\
\pm \\
0.14\end{array}$ & $\begin{array}{l}5.30 \\
\pm \\
0.42\end{array}$ & $\begin{array}{l}5.28 \\
\pm \\
0.18\end{array}$ & $\begin{array}{l}5.50 \\
\pm \\
0.14\end{array}$ & $\begin{array}{l}5.60 \\
\pm \\
0.14\end{array}$ & $\begin{array}{l}5.55 \\
\pm \\
0.07\end{array}$ \\
\hline $\begin{array}{l}\text { Final body weigh } \\
(\mathrm{g} / \mathrm{fish})\end{array}$ & $\begin{array}{l}21.20 \\
\pm \\
0.42 \mathrm{~d}\end{array}$ & $\begin{array}{l}20.65 \\
\pm \\
0.49 \mathrm{~d}\end{array}$ & $\begin{array}{l}23.85 \\
\pm \\
0.35 \mathrm{bc}\end{array}$ & $\begin{array}{l}22.09 \\
\pm \\
0.44 \mathrm{~cd}\end{array}$ & $\begin{array}{l}32.76 \\
\pm \\
0.37 \mathrm{a}\end{array}$ & $\begin{array}{l}26.60 \\
\pm \\
0.28 b\end{array}$ \\
\hline Gain ( g / fish ) & $\begin{array}{l}15.40 \\
\pm \\
0.42 \mathrm{~d}\end{array}$ & $\begin{array}{l}15.35 \\
\pm \\
0.49 \mathrm{~d}\end{array}$ & $\begin{array}{l}18.57 \\
\pm \\
0.35 \mathrm{bc}\end{array}$ & $\begin{array}{l}16.59 \\
\pm \\
0.44 \mathrm{~cd}\end{array}$ & $\begin{array}{l}27.16 \\
\pm \\
0.37 \mathrm{a}\end{array}$ & $\begin{array}{l}21.05 \\
\pm \\
0.28 \mathrm{~b}\end{array}$ \\
\hline $\begin{array}{l}\text { Average daily gain } \\
\text { ( g / fish ) }\end{array}$ & $\begin{array}{l}0.16 \\
\pm \\
0.007 \mathrm{c}\end{array}$ & $\begin{array}{l}0.16 \\
\pm \\
0.007 \mathrm{c}\end{array}$ & $\begin{array}{l}0.22 \\
\pm \\
0.03 \mathrm{~b}\end{array}$ & $\begin{array}{l}0.20 \\
\pm \\
0.01 \mathrm{bc}\end{array}$ & $\begin{array}{l}0.32 \\
\pm \\
0.01 \mathrm{a}\end{array}$ & $\begin{array}{l}0.25 \\
\pm \\
0.07 \mathrm{~b}\end{array}$ \\
\hline $\begin{array}{l}\text { Specific growth rate } \\
\text { (SGR , \% / day) }\end{array}$ & $\begin{array}{l}1.54 \\
\pm \\
0.11 \mathrm{c} \\
\end{array}$ & $\begin{array}{l}1.62 \\
\pm \\
0.04 \mathrm{c} \\
\end{array}$ & $\begin{array}{l}1.79 \\
\pm \\
0.02 \mathrm{~b}\end{array}$ & $\begin{array}{l}1.66 \\
\pm \\
0.05 \mathrm{bc}\end{array}$ & $\begin{array}{l}2.10 \\
\pm \\
0.14 \mathrm{a}\end{array}$ & $\begin{array}{l}1.87 \\
\pm \\
0.04 \mathrm{~b}\end{array}$ \\
\hline Condition factor ( $k$ ) & 2.1 & 2.2 & 2.5 & 2.5 & 3.4 & 1.7 \\
\hline
\end{tabular}

$\mathrm{a}, \mathrm{b}$ and $\mathrm{c}$ value in the same row with different superscript letters are significant different $(\mathrm{P} \leq 0.05)$.

Table 3. Effects of feeding levels and feeding frequencies on Red Tilapia, initial, final and weight gain. Values are Means \pm SD.

\begin{tabular}{lccc}
\hline Classification & $\begin{array}{c}\text { Average initial body } \\
\text { weight } \\
\text { ( g / fish })\end{array}$ & $\begin{array}{c}\text { Average final body } \\
\text { weight } \\
\text { ( g / fish })\end{array}$ & $\begin{array}{c}\text { Average gain in weight( } \\
\text { g/fish) }\end{array}$ \\
\hline Feeding levels\%(F) & & & \\
\hline $\mathbf{2}$ & $5.55 \pm 0.35$ & $20.92 \pm 0.39 \mathrm{~b}$ & $15.37 \pm 0.03 \mathrm{~b}$ \\
\hline $\mathbf{3}$ & $5.39 \pm 0.15$ & $22.97 \pm 1.24 \mathrm{~b}$ & $18.58 \pm 0.07 \mathrm{~b}$ \\
\hline $\mathbf{4}$ & $5.57 \pm 0.04$ & $29.68 \pm 2.35 \mathrm{a}$ & $24.10 \pm 2.32 \mathrm{a}$ \\
\hline $\mathbf{F e e d i n g}$ frequencies $\mathbf{( R )}$ & & & $20.37 \pm 16$ \\
\hline $\mathbf{4}$ & $5.56 \pm 0.37$ & $25.94 \pm 1.56$ & $18.33 \pm 2.04$ \\
\hline
\end{tabular}

$\mathrm{a}$ and $\mathrm{b}$ value in the same row with different superscript letters are significant different $(\mathrm{P} \leq 0.05)$

Table4. Effect of feeding levels and feeding frequencies on Red Tilapia, average daily gain and specific growth rate. Values are Means \pm SD.

\begin{tabular}{ccc}
\hline Classification & Average daily gain ( g / fish / day) & Specific growth rate (\%/day) \\
\hline Feeding levels \% (F ) & & \\
\hline $\mathbf{2}$ & $0.18 \pm 0.00 \mathrm{~b}$ & $1.58 \pm 0.06 \mathrm{~b}$ \\
\hline $\mathbf{3}$ & $0.21 \pm 0.01 \mathrm{~b}$ & $1.72 \pm 0.09 \mathrm{~b}$ \\
\hline $\mathbf{4}$ & $0.28 \pm 0.05 \mathrm{a}$ & $1.98 \pm 0.16 \mathrm{a}$ \\
\hline $\mathbf{4}$ & & $1.81 \pm 0.40$ \\
\hline $\mathbf{6}$ & $0.24 \pm 0.10$ & $1.72 \pm 019$ \\
\hline
\end{tabular}

$\mathrm{a}$ and $\mathrm{b}$ value in the same row with different superscript letters are significant different $(\mathrm{P} \leq 0.05)$.

Table 5. Feed utilization (means \pm SD) at different feeding levels and feeding frequencies

\begin{tabular}{cccccccc}
\hline $\begin{array}{c}\text { Feeding levels \% } \\
\begin{array}{c}\text { Feeding regimes per } \\
\text { day }\end{array}\end{array}$ & $\mathbf{4}$ & $\mathbf{6}$ & $\mathbf{4}$ & $\mathbf{6}$ & $\mathbf{4}$ & $\mathbf{4}$ & $\mathbf{6}$ \\
\hline Feed fed (g/fish) & 20.11 & 19.62 & 32.30 & 33.72 & 55.58 & 48.65 \\
& \pm & \pm & \pm & \pm & \pm & \pm & 0.94 \\
\hline
\end{tabular}


Table 5 Cont.

\begin{tabular}{|c|c|c|c|c|c|c|}
\hline $\begin{array}{l}\text { Feed conversion ratio } \\
\text { (FCR) }\end{array}$ & $\begin{array}{c}1.31 \\
\pm \\
0.03 \mathrm{c}\end{array}$ & $\begin{array}{c}1.28 \\
\pm \\
0.04 \mathrm{c}\end{array}$ & $\begin{array}{c}1.74 \\
\pm \\
0.05 b\end{array}$ & $\begin{array}{c}2.03 \\
\pm \\
0.04 \mathrm{a}\end{array}$ & $\begin{array}{c}2.05 \\
\pm \\
0.04 \mathrm{a}\end{array}$ & $\begin{array}{c}2.31 \\
\pm \\
0.04 \mathrm{a}\end{array}$ \\
\hline $\begin{array}{c}\text { Feed efficiency ratio } \\
\text { (FER) }\end{array}$ & $\begin{array}{c}0.76 \\
\pm \\
0.01 \mathrm{a}\end{array}$ & $\begin{array}{c}0.78 \\
\pm \\
0.01 \mathrm{a}\end{array}$ & $\begin{array}{c}0.57 \\
\pm \\
0.01 \mathrm{~b}\end{array}$ & $\begin{array}{c}0.49 \\
\pm \\
0.00 \mathrm{bc}\end{array}$ & $\begin{array}{c}0.49 \\
\pm \\
0.02 b c\end{array}$ & $\begin{array}{c}0.43 \\
\pm \\
0.01 \mathrm{c}\end{array}$ \\
\hline $\begin{array}{l}\text { Protein efficiency } \\
\text { ratio(PER) }\end{array}$ & $\begin{array}{c}2.37 \\
\pm \\
0.04 \mathrm{a}\end{array}$ & $\begin{array}{c}2.42 \\
\pm \\
0.07 \mathrm{a}\end{array}$ & $\begin{array}{c}1.78 \\
\pm \\
0.06 \mathrm{~b}\end{array}$ & $\begin{array}{c}1.52 \\
\pm \\
0.06 \mathrm{bc}\end{array}$ & $\begin{array}{c}1.51 \\
\pm \\
0.00 \mathrm{c}\end{array}$ & $\begin{array}{c}1.34 \\
\pm \\
0.01 \mathrm{c}\end{array}$ \\
\hline Protein intake (g/fish) & $\begin{array}{c}6.43 \\
\pm \\
0.14 \mathrm{c}\end{array}$ & $\begin{array}{c}6.28 \\
\pm \\
0.21 \mathrm{c}\end{array}$ & $\begin{array}{c}10.34 \\
\pm \\
0.26 \mathrm{~b}\end{array}$ & $\begin{array}{c}10.79 \\
\pm \\
0.34 \mathrm{~b}\end{array}$ & $\begin{array}{c}17.79 \\
\pm \\
0.25 \mathrm{a}\end{array}$ & $\begin{array}{c}15.57 \\
\pm \\
0.17 \mathrm{a}\end{array}$ \\
\hline
\end{tabular}

$\mathrm{a}, \mathrm{b}$ and $\mathrm{c}$ value in the ame row with different superscript letters are significant different $(\mathrm{P} \leq 0.05)$

Table 6. Effect of feeding levels and feeding regimes on Red Tilapia, feed conversion ratio (FCR), feed efficiency (FER), protein efficiency ratio (PER) and feed in take (g/fish) after 12 weeks. Values are means \pm SD.

\begin{tabular}{lllll}
\hline Classification & FCR & FER & PER & Feeding intake ( g / fish ) \\
\hline Feeding levels \%(F) & \multicolumn{5}{l}{} \\
\hline $\mathbf{2}$ & $1.30 \pm 0.02 \mathrm{~b}$ & $0.77 \pm 0.01 \mathrm{a}$ & $2.41 \pm 0.03 \mathrm{a}$ & $19.87 \pm 0.45 \mathrm{c}$ \\
\hline $\mathbf{3}$ & $2.02 \pm 1.03 \mathrm{a}$ & $0.53 \pm 0.06 \mathrm{~b}$ & $1.67 \pm 0.18 \mathrm{~b}$ & $33.01 \pm 1.00 \mathrm{~b}$ \\
\hline $\mathbf{4}$ & $2.18 \pm 0.18 \mathrm{a}$ & $0.46 \pm 0.04 \mathrm{~b}$ & $1.44 \pm 0.13 \mathrm{~b}$ & $52.11 \pm 4.90 \mathrm{a}$ \\
\hline $\mathbf{F e e d i n g}$ frequencies $\mathbf{( R )}$ & & & & \\
\hline $\mathbf{4}$ & $1.7 \pm 0.53$ & $0.61 \pm 0.2$ & $1.91 \pm 0.54$ & $36.0 \pm 25.48$ \\
\hline $\mathbf{6}$ & $1.87 \pm 0.75$ & $0.57 \pm 0.64$ & $1.78 \pm 0.82$ & $34.0 \pm 20.53$ \\
\hline a,b and c value in the same row with different superscript letters are significant different $(\mathrm{P} \leq 0.05)$
\end{tabular}

Table 7. Chemical flesh composition \pm standard deviation at different feeding levels $\%$ and feeding frequencies.

\begin{tabular}{|c|c|c|c|c|c|c|}
\hline \multirow{2}{*}{$\begin{array}{c}\text { Feeding levels \% } \\
\text { Feeding frequencies } \\
\text { (Per day ) }\end{array}$} & \multicolumn{2}{|c|}{2} & \multicolumn{2}{|c|}{3} & \multicolumn{2}{|c|}{4} \\
\hline & 4 & 6 & 4 & 6 & 4 & 6 \\
\hline \multirow{3}{*}{ Dry matter \% } & 21.62 & 21.96 & 22.97 & 23.85 & 23.60 & 23.73 \\
\hline & \pm & \pm & \pm & \pm & \pm & \pm \\
\hline & 0.18 & 0.55 & 0.17 & 0.08 & 0.01 & 0.14 \\
\hline \multirow{3}{*}{ Crude protein \% } & 60.65 & 61.99 & 61.47 & 60.18 & 62.15 & 61.83 \\
\hline & \pm & \pm & \pm & \pm & \pm & \pm \\
\hline & 1.10 & 0.33 & 0.13 & 0.42 & 0.16 & 0.21 \\
\hline \multirow{3}{*}{ Fat \% } & 24.11 & 24.31 & 24.30 & 24.43 & 21.42 & 23.84 \\
\hline & \pm & \pm & \pm & \pm & \pm & \pm \\
\hline & 0.76 & 1.12 & 0.48 & 0.51 & 0.13 & 0.84 \\
\hline \multirow{3}{*}{ Ash \% } & 15.24 & 13.71 & 14.23 & 14.88 & 16.43 & 14.43 \\
\hline & \pm & \pm & \pm & \pm & \pm & \pm \\
\hline & 0.31 & 0.10 & 0.37 & 0.10 & 0.18 & 0.34 \\
\hline
\end{tabular}

Table 8. Effect of feeding levels and feeding regimes on Red Tilapia flesh composition (\%). Values are means \pm SD

\begin{tabular}{lcccc}
\hline classification & Dry matter & Protein & Fat & Ash \\
\hline Feeding levels $\%(\mathbf{F})$ & & & \\
\hline $\mathbf{2}$ & $21.79 \pm 0.24$ & $61.32 \pm 0.94$ & $24.21 \pm 0.14$ & $14.55 \pm 2.03$ \\
\hline $\mathbf{3}$ & $23.41 \pm 0.62$ & $60.82 \pm 0.91$ & $24.36 \pm 0.09$ & $14.54 \pm 0.44$ \\
\hline $\mathbf{4}$ & $23.66 \pm 0.06$ & $61.99 \pm 0.23$ & $22.63 \pm 1.71$ & $15.43 \pm 1.41$ \\
\hline Feeding frequencies $(\mathbf{R})$ & & & & \\
\hline $\mathbf{4}$ & $22.73 \pm 1.43$ & $61.42 \pm 1.06$ & $23.27 \pm 2.28$ & $15.30 \pm 1.56$ \\
\hline $\mathbf{6}$ & $23.18 \pm 1.50$ & $61.33 \pm 1.42$ & $24.14 \pm 0.44$ & $14.33 \pm 0.81$ \\
\hline F X R & & &
\end{tabular}




\section{References}

Al-Amoudi , M. M . (1987). Acclimation of commercially cultured Oreochromis species to sea water. An experimental study.Aquaculture , $65: 333$ - 342 .

Al-Souti,A., Al-Sabahi,J., Soussi,B., Goddard,S.(2012).

The effects of fish oil-enriched diets on growth, feed conversion and fatty acid content of red hybrid tilapia, Oreochromis sp. Food Chemistry, Volume 133, Issue 3, 1 August 2012, Pages 723727

Andrews, J.W. and J. W. Page (1975). The effects of feeding frequency of feeding on culture of catfish. Trans. Am. Fish. Soc. 104,317-321.

Association of Official Analytical Chemists (1990). Official Methods of Analysis (AOAC), $15^{\text {th }} \mathrm{Ed}$., Washington D. C., U.S.A.

APHA (1989): American Public Health Association. Standard methods for the examination of water and waste water, $17^{\text {th }}$ edition, Washington, D.C., U.S.A.

Bashamohideen, M. and Parvatheeswararao, V., (1976). Adaptation to osmotic stress in the freshwater euryhaline teleost . Tilapia mossambica.Zool.Anz., Jena. 197 (1/2) 47 - 56.

Cheong,L.,Chan,F.K.,Wong,F.J.

and Chou,R.(1987) . Observation on the

Culture of red tilapia ( Oreochromis niloticus hybrid) in sea water under intensive tank condition using a biodrum Singapore. J. Prim . Ind., 15: 42-56.

Clark , W.O.; Watanabe, Olla. B. L. and Wicklumed, R.I. (1990). Growth feed conversion and protein Utilization of Florida Red Tilapia fed isocaloric diets with different protein levels. 85 In sea water pools Aquaculture, 88(1):75 -

Duncan,D.B. (1955). Multiple - range and multiple F Test . Biometrics , 11:1-42.

Doudet,T.(1992). Brackish water tolerance of some species and hybrids of Oreochromis for use in lagoon aquaculture (Ivory coast). Aquaculture, $102: 275$ - 288.

El-Dakar,A.Y.(1999). Effect of different feeding levels on performance of rabbit fish, Siganus rivulates, fingerlings.Egypt .J.Aquat. Biol. of fish., Vol.3, No4:35 - 56.

El-Sayed , A.M. (2002). Effects of stocking density and feeding levels on growth and feed efficiency of Nile Tilapia (O. niloticus) fry. J. Aquaculture Research, 33: 621 - 626.

El-Sayed,A.M. (2006). Tilapia Culture in Salt Water : Environmental Requirments , Nutritional Implications and Economic Potentials. Editores : L. Elizabeth Cruz Suarez, Denis Ricque Marie, Mireya Tapia Salazar, Matha G. Nieto Lopez,David A. Villarreal Cavazos, Ana C.PuelloCruzy Armando Garcia Ortega.
Avances en Nutricion Acuicola Vni.Vin Simposium Internacional de Nutricion Acuicola.15-17.

Gunner,Y.,Ozden,O.,Cagugan, H., Altunok, M., and Kizak, V. (2005).

Effects of salinity on the osmoregulatory functions of the gills in Nile Tilapia (O. niloticus) .Turk .J. Vet. Anim. Sci. 29: 1259 - 1266.

Jarboe, H.H\& W. J. Grant (1996).Effects of feeding time and frequency on growth of channel catfish Ictalurus punctatus in closed recirculating raceway systems. Journal of world Aquaculture society 27:235 - 239.

Kamal AMDM and Mari, G.C. (2005). Salinity tolerance in superior genotypes of tilapia, Oreochromisniloticus , O. mossambicus and their hybrids . Aquaculture , 247:189 - 201.

Macintosh ,D.J .and Silva ,S.S. (1984). The influence of stocking density and food ration on fry survival and growth in O. mossambicus and O. niloticus, O. aureus male hybrids reared in a closed circulated System .J. Aquaculture , 41: $345-358$

Ng,W., Chon ,C. , Wang,C. and Romano,N.(2013) .Effects of dietary fish and vegetable oils on the growth, tissue fatty acid composition, oxidative stability and vitamin $\mathrm{E}$ content of red hybrid tilapia and efficacy of using fish oil finishing diets. Aquaculture .Volumes 372-375, Pages 97-110

N R C (1993): Nutritional requirements of fish. National Academy Press, National Research Council, Washington D.C.

Ogata, H.Y. and Shearer ,K. D. (2000).Influence of dietary fat and adiposity on feed intake of juvenile red sea bream (Pagrus major L.). J. Aquaculture, 189: 237 - 246.

Orachunwong,C., Thammasart,S. and Lohawatankul,C. (2001). Recent development in tilapia feeds . Proceeding of the Tilapia 2001. International Tech .And Trade Conference on Tilapia , KaualaLumpure , Malaysia, p.p 113 122.

Philippart,J-CL. And Ruwet ,J-CL.(1982). Ecology and distribution of Tilapia. In :Pullin , R.S.V. and LoweMoconnell, R.H. (eds). The biology procceeding No. 7., ICLARM , Manila , Philippines, pp.15 - 59.

Pongthana , N., Ponzoni,R.W. and Nguyen,N.H. ( 2010). Comparative performance of four red tilapia strains and their crosses in fresh- and saline water environments . Aquaculture, Volume 308, Supplement 1, 2010, Pages S109S114.

Riche,M., Haley D.I., Oetker, M. . Garbrecht, S. and Garling D.L.(2004). Effect of feeding frequency on gastric evacuation and the return of appetite in tilapia Oreochromis niloticus (L.). Aquaculture, Volume 234, Issues 1-4, 657-673. 
Santiago, C.B., Aldoba , M. B. and Reyes, O.S. (1987).Influence on feeding rate and diet from on growth and survival of Nile Tilapia( $O$. niloticus) fry.J. Aquaculture, 64: 277 - 282.

SAS (Statistical Analysis System) (1993): SAS/STAT User's Guide Release 6.03 edition. SAS Institute Inc. Cary. NC.

Sayed, S. H. (2005). Effect of feeding rates on performance of mono-sex Nile Tilapia reared in fertilized earthen ponds . Egyptian .J. Nutrition and feeds, 8(2): 249 - 256.

Sirol , R.N., Andrade , D.R. and Solaria, A.J. (2000). Growth and body composition of Red Tilapia fingerlings ( $O$. niloticus $X O$. aureus ) submitted to different feeding levels. In tilapia aquaculture in the $21^{\text {st }}$ Century. Proceeding from $5^{\text {th }}$. In. Symp . On Tilapia Aquaculture (ed, by K. Fitzsimons and J.C. Filho) . 382 - 389 . Rio De Jeneiro, Brazil , 3 - 7 Sept . 2000.

Steel, R. G.and J.H. Torrie (1980). Principles and procedures of statistics, McGraw- Hill, Inc London, $\mathrm{u}$. $\mathrm{k}$.

Thompson,K.R.,Webster,C.D.,Morgan,A.M. and Grisby, E.J. (2000).

Effects of different feeding frequencies on growth , body compositions and fillet composition of juvenile Sunshine Bass ,

(Morone chrysops X M. saxatilis), growth indoor . J. of Applied Aquaculture, vol.10(2): 55 - 65.

Thouard, E., Soletchnik, P. And Marion, J.P. (1990). Selection of finfish

Species for aquaculture development in Martinique (F.W.I. ) Aquaculture , 89 : 193 - 197.

Tung, Pen-Hasing and Shiau,Yen (1991). Effects of meal frequency on growth performance of hybrid tilapia, ( Oreochromis niloticus X O. aureus), fed different carbohydrate diets . Aquaculture 92 : 343- 350.

Villegas,C.T.(1990).Evalution of the salinity tolerance of Oreochromis mossambicus , O. niloticus and their F1 hybrids . Aquaculture , 85: 281-292..

Watanabe, W. O., French, K. E., Ellingson, L. J., Wicklund , R. I. and Olla, B. L. (1988). Further investigations on the effects of salinity on growth in Florida Red Tilapia; evidence for the influence of behavior. In: R. S. V. Pullin. T. Bhukaswan, K. Tonguthia and J. L. Maclean ( Editors ). The second International Symposim on tilapia in aquacul. ICLARM ConferenceProceedings 15. Department of Fisheries .Bangkok, and International Center Lining Aquatic Resources Management. Manila, Philippines .pp. 525 - 530.

Watanabe, W. O., Clark , J. H. , Dunham, J. B. , Wicklund, R. I. and Olla, L.(1990) .Culture of Florida Red Tilapia in marine cages: the effect of stocking density and dietary protein on growth. .Aquaculture 90 (2) 123 134.

Watanabe, W.O. Kuo C.M. and Huang, M.C (1985). The ontogeny.of

salinity tolerance in the tilapia ( $O$. aureus ) $/ O$. niloticus and $O$. mossambicus X O. niloticus hybrid spawned and reared in fresh water. Aquaculture, 47: 353-367.

Wing-Keong, N.G.,Kim-Sun, L.u., Roshada Hashim and Ahyaudin, A.(2000). Effects of feeding rate on growth, feed utilization and body composition of a tropical bagrid cat fish . Aquaculture International 8: 19 - 29.

$$
\begin{aligned}
& \text { تأثير مستويات و عدد مرات الغذاء على النمو و الكفاءة الغذائية لأصباعيات البلطي الأحمر }
\end{aligned}
$$

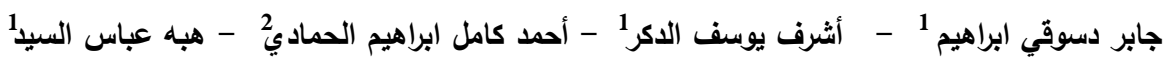

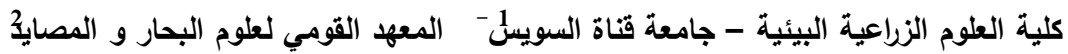

$$
\begin{aligned}
& \text { الملذص العربي } \\
& \text { أجريت هذه الدراسة بمركز بحوث الأستزراع البحري بكلية الزراعية البيئية بجامعة قناة السويس - العريش لدراسة } \\
& \text { تأثثير مستويات و عدد مرات الغذاء على النمو و الكفاءة الغذائية. }
\end{aligned}
$$

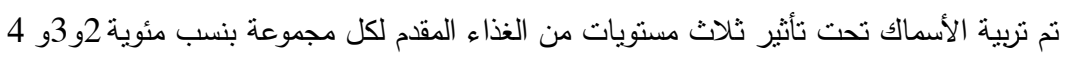

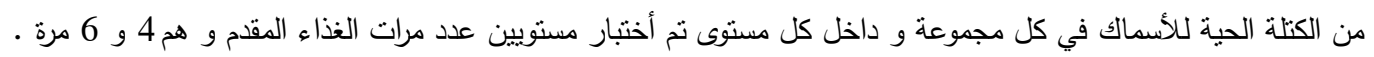

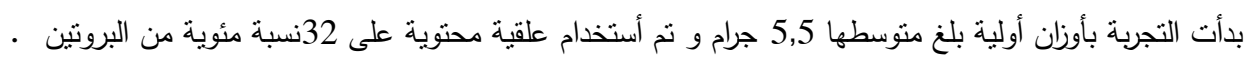

$$
\begin{aligned}
& \text { و كانت أهم النتائج المتحصل عليها هي : النعان } \\
& \text { حققت الأسماك التي تم تقديم الغذاء لها بنسبة مئوية } 4 \text { من الكتلة الحية و نم تقنيمها و و تقديمها للأسماك على } 4 \text { مرات } \\
& \text { أفضل الننائج حيث كان الوزن النهائي لها 29,68+- 4,35 جم / سمك و معدل الزيادة اليومية خلال فنترة النجربة الني أستمرت }
\end{aligned}
$$

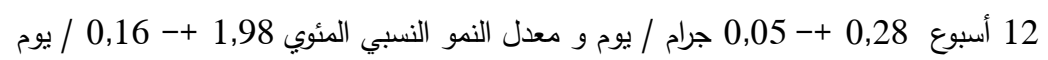

